\title{
Reuse of treated domestic sewage for biquinho pepper cultivation
}

\section{Reúso de aguas domésticas tratadas en el cultivo de la pimienta de pico}

Raimundo Rodrigues Gomes Filho ${ }^{{ }^{*}}$, Simone de Oliveira Feitosa ${ }^{3}$, Clayton Moura de Carvalho ${ }^{4}$, Gregorio Guirado Faccioli ${ }^{1}$, Tatiana Pacheco Nunes ${ }^{2}$, Renisson Neponuceno de Araújo Filho ${ }^{5}$, Silvaneide Lobo da Silva ${ }^{3}$, Ronaldo Souza Resende ${ }^{6}$, Rodrigo Couto Santos ${ }^{7}$, Moacyr Cunha Filho ${ }^{8}$, Juan Mariano Camarillo Naranjo ${ }^{9}$

Originales: Recepción: 02/06/2020 - Aceptación: 22/03/2021

\begin{abstract}
This study aimed to evaluate the reuse of treated domestic sewage in biquinho pepper (Capsicum chinense L.) cultivation under different irrigation regimes. The experiment was carried out in a greenhouse, in a randomised block design with a $3 \times 4$ factorial scheme, with four replications. Forty-eight pepper plants were subjected to three treated domestic sewage concentrations $(0,50$, and $100 \%)$ and four irrigation depths $(75,100,125$, and $150 \%$ of the crop evapotranspiration - ETc). Data for ETc estimation were obtained from an automatic meteorological station, which was installed in the greenhouse. The results showed that irrigation depths corresponding to 125 and $150 \%$ of the ETc at a concentration of $100 \%$ treated domestic sewage resulted in higher plants. Moreover, longer fruits were obtained when plants were subjected to $100 \%$ ETc at $100 \%$ treated domestic sewage. The studied irrigation depths influenced pepper fruit total weight and yield. No treated domestic sewage concentrations significantly influenced the variables analysed. Treated domestic sewage reuse can constitute an alternative for quality water saving and for chemical fertilisation of biquinho pepper crop.
\end{abstract}

\section{Keywords}

Capsicum chinense $L$. $\bullet$ water reuse $\bullet$ evapotranspiration $\bullet$ greenhouse

1 Federal University of Sergipe. Department of Agricultural Engineering. Av. Marechal Rondon. s/n. Jd. Rosa Elze. C. P. 49100-000. São Cristóvão. SE. Brazil.

2 Federal University of Sergipe. Food Engineering Department. Av. Marechal Rondon. s/n. Jd. Rosa Elze. C. P. 49100-000. São Cristóvão. SE. Brazil.

3 Federal University of Sergipe. Graduate Program in Water Resources.

4 Federal Institute of Bahia - IF Baiano Campus Serrinha. Estrada Vicinal de Aparecida. s/n. C. P. 48700-000. Serrinha. BA. Brazil.

5 Federal University of Tocantins. Rua Badejós. Lote 7. Chácaras 69/72. s/n. C. P. 77402-970. Gurupi. TO. Brazil.

6 Embrapa Tabuleiros Costeiros. Av. Beira Mar. 3250 - Jardins. C.P. 49040-490. Aracaju. SE. Brazil.

7 Federal University of Grande Dourados. R. João Rosa Góes,. 1761 Vila Progresso. C. P. 79825-070. Dourados. MS. Brazil.

8 Federal Rural University of Pernambuco. Rua Dom Manuel de Medeiros. s/n. Dois irmãos. C. P. 52171-900. Recife. PE. Brazil.

9 University of Seville, Department of Physical Geography and Regional Geographic Analysis. Calle San Fernando. 4. 41004. Seville. Spain. 


\section{RESUMEN}

Este estudio tuvo por objeto evaluar el reúso de aguas domésticas tratadas en el cultivo del pimiento de pico (Capsicum chinense L.) sometido a diferentes niveles de reposición de agua. El experimento se llevó a cabo en un invernadero en un diseño de bloques aleatorios en un esquema factorial $3 \times 4$, con cuatro repeticiones. Cuarenta y ocho pimientas fueron sometidas a concentraciones de 0,50 y 100\% de reúso de aguas domésticas tratadas y cuatro niveles de reposición de agua correspondientes al 75, 100, 125 y 150\% de la evapotranspiración del cultivo (ETc). Los datos para la estimación de la evapotranspiración de los cultivos se obtuvieron de una estación meteorológica automática instalada dentro del invernadero. Los niveles de reposición de agua del 125 y $150 \%$ de la evapotranspiración de los cultivos con una concentración del 100\% de reúso de aguas domésticas tratadas proporcionaron mayores alturas de las plantas. Se obtuvieron mayores longitudes del fruto del pimiento cuando se sometió a una ETc del $100 \%$ con una concentración del 100\% de reúso de agua domésticas tratadas. Los niveles de reposición de agua influyeron en la producción total y la productividad de los frutos del pimiento. Las concentraciones de reúso de agua domésticas tratadas no influyeron significativamente en las variables analizadas. El reúso de agua domésticas tratadas puede ser una alternativa para reducir el uso de agua de mejor calidad y la fertilización química en el cultivo del pimiento de pico.

\section{Palabras clave}

Capsicum chinense $L$. • reúso de agua • evapotranspiración • invernadero

\section{INTRODUCTION}

Pepper cultivation has assumed great importance for the Brazilian and world populations. Biquinho is a pepper variety (Capsicum chinense L.) widely grown by small farmers due to its high yield potential, gastronomic value, market acceptance, and financial return (3). It stands out for adding commercial value depending on the region of sale and has been increasingly valued in the consumer market, especially for consumption in the form of pickles and for a mild flavour and absence of pungency (9). Crop evapotranspiration knowledge during different phenological stages helps determine crop water requirements and water use efficiency (5).

The cultivation of peppers in north-eastern Brazil is affected by local water scarcity due to irregular rainfall and high evapotranspiration rates (13). In this sense, irrigation constitutes a valuable alternative for its production in this region. However, due to low water availability, crop irrigation is not always possible (18). Thus, reusing treated water in irrigated agriculture is a way of providing good quality water in optimum amounts for this purpose, seeking to save water for human and animal consumptions (14).

Reuse of water for irrigation purposes can benefit crops in terms of nutrient supply, reducing the need for synthetic fertilisers (2). Queiroz et al. (2015) observed that, despite several benefits, unrestricted irrigation with urban effluent may imply health and environmental risks. Besides supplying organic matter and nutrients to the soil, it also increases salt contents, which, depending on the concentration, can compromise crop quality and reduce soil osmotic potential, thus limiting productive capacity.

Several studies on wastewater reuse in agriculture have been conducted on chilli pepper (18), okra (15), papaya (10), white oats (4), and lettuce (8). Therefore, this study aimed to evaluate the effect of reusing treated domestic sewage in biquinho pepper (Capsicum chinense $L$.) growth under different irrigation regimes.

\section{MATERIAL AND METHODS}

The experimental area is located at $30 \mathrm{~m}$ above sea level. According to Köppen's classification, the local climate is humid tropical with a dry season in the summer. The region has an average annual temperature of $25.2^{\circ} \mathrm{C}$ and rainfall of $1300 \mathrm{~mm}$, which is concentrated from April to September. The soil used is classified as Ultisols (17). 
Forty-eight biquinho pepper (Capsicum chinense L.) plants were grown in 21-L plastic containers arranged on a bench inside a greenhouse. The experiment was carried out in a randomized block design and arranged in a $3 \times 4$ factorial scheme, with three treatments and four replications. The plants were subjected to three treated domestic sewage concentrations $(0,50$, and $100 \%)$ and four irrigation regimes (depths), which corresponded to $75,100,125$, and $150 \%$ of the crop evapotranspiration (ETc).

The plants were fertilised at transplanting time according to soil analysis, applying: urea $\left(1 \mathrm{~g} \mathrm{pot}^{-1}\right), \mathrm{P}_{2} \mathrm{O}_{5}\left(4.2 \mathrm{~g} \mathrm{pot}^{-1}\right)$, and $\mathrm{K}_{2} \mathrm{O}\left(1.5 \mathrm{~g} \mathrm{pot}^{-1}\right)$. After 30 days, topdressing was performed by applying urea $\left(0.5 \mathrm{~g} \mathrm{pot}^{-1}\right)$ and $\mathrm{K}_{2} \mathrm{O}\left(0.75 \mathrm{~g} \mathrm{pot}^{-1}\right)$. After transplantation, the plants were supplied with $100 \%$ water. Weather data used for reference evapotranspiration were obtained from an automatic meteorological station, which was installed in the greenhouse. Crop coefficients of greenhouse-grown pepper used to determine crop evapotranspiration were $0.74,1.38,1.40,1.17$, and 1.02 (16).

The parameters evaluated were plant height, fruit length, and stem diameter, which were measured with a millimetre ruler and a pachymeter. Fruit weight was determined by collecting and drying fruit in an oven at $60^{\circ} \mathrm{C}$ for 24 hours. Then, the material was weighed on a precision scale to an accuracy of $0.01 \mathrm{~g}$. Pepper yield $\left(\mathrm{kg} \mathrm{ha}^{-1}\right)$ was obtained according to fruit production per plant and the area occupied by each plant.

Data were submitted to ANOVA analysis of variance, and means were compared by Tukey's test. Regression equations were generated for the parameters fruit weight and yield. Statistical analyses were performed using the statistical software SISVAR 5.6 (7).

\section{RESULTS AND DISCUSSION}

ANOVA showed that all irrigation regimes had significant effects on the studied parameters at $1 \%$ significance by the F-test (table 1). The sewage concentrations had no significant effect on the evaluated parameters, but their interaction with irrigation regimes had a significant effect on plant height and fruit length.

$\left.{ }^{* *}\right) p$-value $\leq 0.01$ ${ }^{*}$ ) p-value $\leq 0.05$; (ns) non-significant at $5 \%$ probability level by the F-test.

(**) Efecto significativo al nivel de probabilidad del 1\%; $\left({ }^{*}\right)$ significativo al $5 \%$ de probabilidad;

(s) no significativo al

nivel de probabilidad del $5 \%$ por la prueba $\mathrm{F}$.
Table 1. ANOVA for plant height $(\mathrm{cm})$, fruit length $(\mathrm{cm})$, and stem diameter $(\mathrm{cm})$ in response to irrigation regimes and treated domestic sewage concentrations.

Tabla 1. Resumen del ANOVA para altura de la planta $(\mathrm{cm})$, longitud del fruto $(\mathrm{cm})$ y diámetro del tallo $(\mathrm{cm})$ en respuesta a los niveles de reposición de agua y las concentraciones de reúso de aguas domésticas tratadas.

\begin{tabular}{|l|c|c|c|c|}
\cline { 2 - 5 } \multicolumn{1}{c|}{} & \multicolumn{4}{c|}{ Average square } \\
\hline \multicolumn{1}{c|}{ Variation Source } & DF & Plant height & Fruit length & Stem diameter \\
\hline Irrigation level (L) & 3 & $117.69^{* *}$ & $0.22287^{* *}$ & $4.55608^{* *}$ \\
\hline Sewage concentration (C) & 2 & $24.00 \mathrm{~ns}$ & $0.08100 \mathrm{~ns}$ & $1.37479 \mathrm{~ns}$ \\
\hline Interaction (L x C) & 6 & $51.65 *$ & $0.25642^{* *}$ & $1.25004 \mathrm{~ns}$ \\
\hline Treatment & 11 & $64.63^{* *}$ & $0.21538^{* *}$ & $2.17437 *$ \\
\hline Block & 3 & $42.07 \mathrm{~ns}$ & $0.00266^{*}$ & $0.55655 \mathrm{~ns}$ \\
\hline Residue & 33 & 20.47 & 0.03859 & 0.77309 \\
\hline
\end{tabular}

Tavares et al. (2019) found no significant effect of treated wastewater irrigation on pepper height, but on stem diameter and leaf number. Faccioli et al. (2017) also found no significant effect of treated wastewater on cowpea bean height, thus differing our study (table 1). Silva et al. (2019) verified no significant effect of different wastewater irrigation depths on chilli pepper fruit length, unlike our results. Tukey's test $(p \leq 0.05)$ showed that sewage concentrations significantly affected plant height for $\mathrm{L}_{1}$ at $\mathrm{C}_{3}$ (table 2, page 179). 
Table 2. Tukey's test for average plant height and fruit length in response to irrigation regimes and concentrations of treated domestic sewage.

Tabla 2. Prueba de Tukey para la altura media de la planta y la longitud media del fruto en respuesta a los niveles de reposición de agua y las concentraciones de reúso de aguas domésticas tratadas.

\begin{tabular}{|c|c|c|c|}
\hline \multicolumn{4}{|c|}{ Plant height (cm) } \\
\hline \multicolumn{4}{|c|}{ Sewage concentration } \\
\hline Irrigation regime (mm) & $\mathbf{C}_{1}$ & $\mathbf{C}_{2}$ & $\mathbf{C}_{3}$ \\
\hline $\mathrm{L}_{1}$ & $31.00 \mathrm{aA}$ & $35.21 \mathrm{aA}$ & $24.96 \mathrm{bB}$ \\
\hline $\mathrm{L}_{2}$ & $33.00 \mathrm{aA}$ & $31.58 \mathrm{aA}$ & $29.12 \mathrm{bA}$ \\
\hline $\mathrm{L}_{3}$ & $32.17 \mathrm{aA}$ & $36.12 \mathrm{aA}$ & $39.62 \mathrm{aA}$ \\
\hline $\mathrm{L}_{4}$ & $35.67 \mathrm{aA}$ & $36.71 \mathrm{aA}$ & $36.87 \mathrm{aA}$ \\
\hline & Fruit length (cm) \\
\hline & Sewage concentration \\
\hline Irrigation regime (mm) & $\mathrm{C}_{1}$ & $\mathbf{C}_{2}$ & \\
\hline $\mathrm{L}_{1}$ & $1.64 \mathrm{bA}$ & $1.87 \mathrm{aA}$ & $1.64 \mathrm{bA}$ \\
\hline $\mathrm{L}_{2}$ & $1.75 \mathrm{bB}$ & $2.15 \mathrm{aA}$ & $2.15 \mathrm{aA}$ \\
\hline $\mathrm{L}_{3}$ & $2.12 \mathrm{aA}$ & $1.88 \mathrm{aA}$ & $1.92 \mathrm{aA}$ \\
\hline $\mathrm{L}_{4}$ & $2.19 \mathrm{aA}$ & $2.06 \mathrm{aA}$ & $1.86 \mathrm{aB}$ \\
\hline
\end{tabular}

$\mathrm{L}_{1}: 75 \%, \mathrm{~L}_{2}: 100 \%, \mathrm{~L}_{3}: 125 \%$, and $\mathrm{L}_{4}: 150 \%$ of the crop evapotranspiration (ETc). $\mathrm{C}_{1}: 0 \%$ of treated domestic sewage $+100 \%$ water supply, $\mathrm{C}_{2}: 50 \%$ treated domestic sewage $+50 \%$ of water supply, $\mathrm{C}_{3}: 100 \%$ treated domestic sewage. Means followed by the same letter, lower-case in the column and upper-case in the row, did not differ statistically.

$\mathrm{L}_{1}: 75 \%, \mathrm{~L}_{2}: 100 \%, \mathrm{~L}_{3}: 125 \%$ y $\mathrm{L}_{4}: 150 \%$ de la evapotranspiración del cultivo (ETc). $\mathrm{C}_{1}: 0 \%$ de reúso de aguas domésticas tratadas y $100 \%$ de agua del sistema de suministro, $\mathrm{C}_{2}: 50 \%$ de reúso de aguas domésticas tratadas

$+50 \%$ de agua del sistema de suministro, $C_{3}: 100 \%$ de reúso de aguas domésticas tratadas. Los promedios

seguidos de las mismas letras no difieren estadísticamente. En columna letras minúsculas y en la línea letras mayúsculas.

$\mathrm{L}_{3}$ and $\mathrm{L}_{4}$ irrigation regimes had effects on plant height only in plants receiving $\mathrm{C}_{1}$, thus increasing plant heights. When analysing different irrigation depths for biquinho pepper cultivation on different substrates, Silva et al. (2016) found that an irrigation depth of $100 \%$ of the ETc produced higher plants $(23 \mathrm{~cm})$, which is significantly lower than our result $(39.62 \mathrm{~cm})$ at $\mathrm{L}_{3}$. However, opposite to our study, these authors found higher plants when $100 \%$ water was applied (table 2). Nascimento et al. (2021) observed that water stress caused by deficit irrigation reduced plant height, seed mass, and pod yield of peanut, while full irrigation (100\% of crop evapotranspiration replacement) led to yields of 4,141 to $5,102 \mathrm{~kg} \mathrm{ha}^{-1}$, approximately three times higher than those obtained with the lowest irrigation level ( $8 \%$ replenishment of crop evapotranspiration).

In our study, the longest fruits $(2.19 \mathrm{~cm})$ were obtained at $\mathrm{L}_{4}$, with $\mathrm{C}_{1}$, thus longer than that of $\mathrm{C}_{3}$. Conversely, the smallest fruits $(1.64 \mathrm{~cm})$ were produced when the plants were subjected to $\mathrm{L}_{1}$ and at $\mathrm{C}_{3}$.

The irrigation regime effect was significant at a 5\% probability for average fruit weight and yield. No significant effect was observed for concentrations of treated domestic sewage or their interactions with irrigation regimes for the studied parameters (table 3).

Table 3. Summary of ANOVA for data on average fruit weight and yield in response to

(**) $p$-value $\leq 0.01$ $\left(^{*}\right) p$-value $\leq 0.05$; (ns) non-significant at $5 \%$ probability level by the F-test

$\left.{ }^{* *}\right)$ Efecto significativo al nivel de probabilidad del 1\%; $\left(^{*}\right)$ significativo al 5\% de probabilidad;

(s) no significativo al

nivel de probabilidad del $5 \%$ por la prueba $\mathrm{F}$.

\section{irrigation regimes and concentrations of treated domestic sewage.}

Tabla 3. Resumen del ANOVA de los datos del peso promedio de la fruta y la productividad en respuesta a los niveles de reposición de agua y las concentraciones de reúso de aguas domésticas tratadas.

\begin{tabular}{|l|c|c|c|}
\cline { 2 - 4 } \multicolumn{1}{c|}{} & \multicolumn{3}{c|}{ Mean square } \\
\hline \multicolumn{1}{c|}{ Variation Source } & DF & Fruit weight & Fruit yield \\
\hline Irrigation regime (L) & 3 & $1035.68369 *$ & $161825.57892 *$ \\
\hline Sewage concentration (C) & 2 & $411.52465 \mathrm{~ns}$ & $64300.73272 \mathrm{~ns}$ \\
\hline Interaction (Lx C) & 6 & $439.82768 \mathrm{~ns}$ & $68723.06810 \mathrm{~ns}$ \\
\hline Treatment & 11 & $597.18786 \mathrm{~ns}$ & $93310.60098 \mathrm{~ns}$ \\
\hline Block & 3 & $465.54059 \mathrm{~ns}$ & $72740.71853 \mathrm{~ns}$ \\
\hline Residue & 33 & 356.50274 & 55703.55354 \\
\hline
\end{tabular}


Regression equations were adjusted to express changes in average fruit weight (g) and yield $\left(\mathrm{t} \mathrm{ha}^{-1}\right)$ as a function of the irrigation depths, respectively (figure 1 ).

Maximum yield of biquinho pepper was $14.3 \mathrm{t} \mathrm{ha}^{-1}$, achieved by applying $143.4 \%$ ETc irrigation (figure 1). This result is lower than that found by Barroca et al. (2015), who obtained a maximum production of $43.6 \mathrm{t} \mathrm{ha}^{-1}$ for the variety 'Pimenta-de-Cheiro' when applying $119.6 \%$ ETo. However, the same authors found a lower value for the variety 'Dedo-de-Moça', which was $15.8 \mathrm{t} \mathrm{ha}^{-1}$ when applying $113.6 \%$ ETo. In our study, maximum average fruit weight was $99.5 \mathrm{~g}$ for a water supply of $142.5 \% \mathrm{ETc}$ (figure 1).
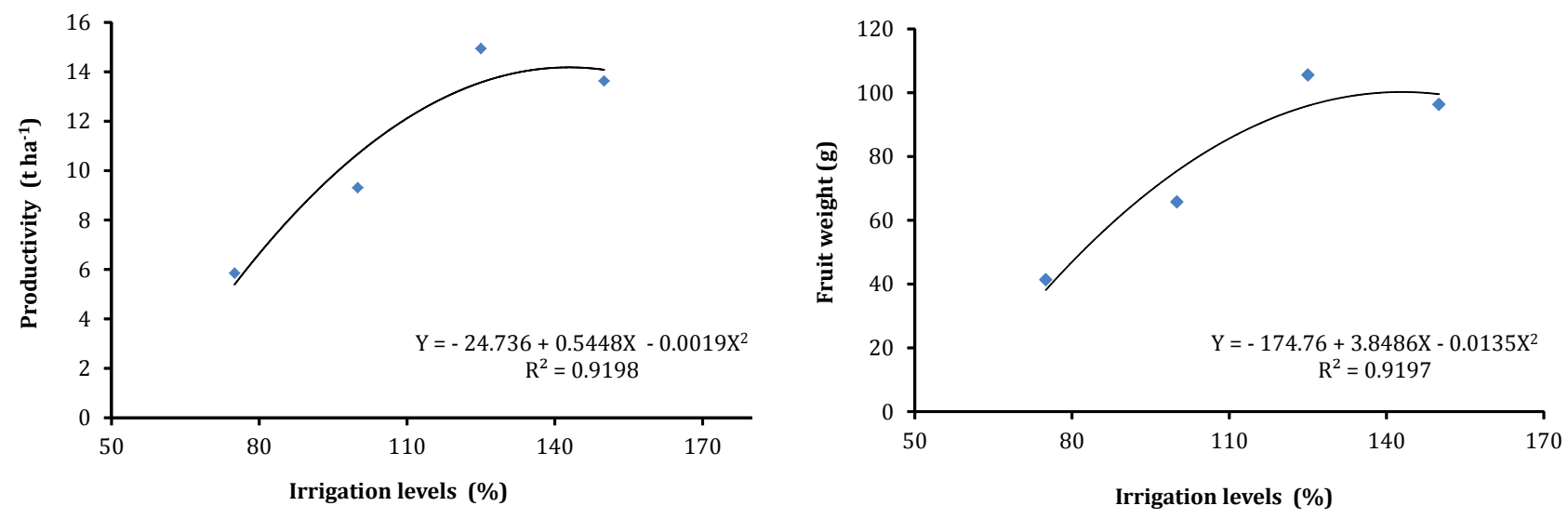

Figure 1. Regression analysis for average yield (a) and average fruit weight (b) of biquinho pepper plants as a function of irrigation regimes.

Figura 1. Análisis de regresión para productividad (a) y peso medio de la fruta (b), en función de los niveles de reposición de agua para el pimiento de pico.

\section{ConCLUSION}

Growth of biquinho pepper with treated domestic sewage can bring benefits in terms of crop nutrient supply, while environmental impact can be reduced by replacing chemical fertilisers. Treated domestic sewage reuse can constitute an alternative both for quality water saving and for chemical fertilization of biquinho pepper crops.

\section{REFERENCES}

1. Barroca, M. V.; Bonomo R.; Fernandes, A. A.; Souza, J. M. 2015. Lâminas de irrigação nos componentes de produção das pimentas 'De cheiro' e 'Dedo-de-Moça'. Revista Agro@mbiente On-line. 9(3): 243-250. https://doi.org/10.18227/1982-8470ragro.v9i3.2342

2. Becerra-Castro, C.; Lopes, A. R.; Vaz-Moreira, I.; Silva, E. F.; Manaia, C. M.; Nunes, O. C. 2015. Water reuse in irrigation: a microbiological perspective on implications in soil fertility and human and environmental health. Environment International. 75: 117-135. https://doi. org/10.1016/j.envint.2014.11.001

3. Beloti, I. F.; Azevedo, B. N. R.; Maciel, G. M.; Peres, H. G; Momesso, M. P.; Alves, I. M. 2019. Agronomic performance and physiological quality of pepper seeds under different planting system. Journal of Neotropical Agriculture. 6(4): 57-62. https://doi.org/10.32404/rean.v6i4.3432

4. Coelho, A. P.; Faria, R. T. de, Barbosa, A. M. da S.; Dalri, A. B.; Rosalen, D. L. 2019. Agronomic performance of white oats cultivated under fertigation with treated sewage effluent and definition of critical limits of Normalized Difference Vegetation Index. Bragantia. 78: 553-563. http:// dx.doi.org/10.1590/1678-4499.20190082

5. Curto, L.; Covi, M.; Gassmann, M. I. 2019. Actual evapotranspiration and the pattern of soil water extraction of a soybean (Glycine max) crop. Revista de la Facultad de Ciencias Agrarias. Universidad Nacional de Cuyo. Mendoza. 51(2): 125-141. 
6. Faccioli, G. G.; Ramos, F. S. M.; Santana, F. S.; Dantas, C. K. S. 2017. Análise das características agronômicas e microbiológicas do feijão- caupi (Vigna ungiculada (L.) Walp.) brs novaera e brs guariba com aplicação de água residuária tratada. Revista Brasileira de Agricultura Irrigada. 11 (5): 1707-1713. 10.7127/rbai.v11n500761

7. Ferreira, D. F. 2011. Sisvar: um sistema computacional de análise estatística. Ciênc. Agrotec. [online]. 35 (6): 1039-1042. https://doi.org/10.1590/S1413-70542011000600001

8. Gomes Filho, R. R.; Santos, M. R. A.; Carvalho, C. M.; Faccioli, G. G.; Nunes, T. P.; Santos, R. C.; Valnir Junior, M.; Lima, S. C. R. V.; Mendonça, M. C. S.; Geisenhoff, L. O. 2020. Microbiological quality of lettuce irrigated with treated water reuse. International Journal of Development Research. 10(4): 34989-34992.

9. Heinrich, A. G.; Ferraz, R. M.; Ragassi, C. F.; Reifschneider, F. J. B. 2015. Caracterização e avaliação de progênies autofecundadas de pimenta biquinho salmão. Horticultura Brasileira. 33(4): 465-470. https://doi.org/10.1590/S0102-053620150000400010

10. Khaliq, S. J. A.; Al-Busaidi, A.; Ahmed, M.; Al-Wardy, M.; Agrama, H.; Choudri, B. S. 2017. The effect of municipal sewage sludge on the quality of soil and crops. Int J Recycl Org Waste Agricult. 6: 289-299. https://doi.org/10.1007/s40093-017-0176-4

11. Nascimento de Oliveira França, P.; Teixeira Faria, R.; Carrega, W. C.; Prates Coelho, A.; Godoy, I. G.; Palaretti. L. F. 2021. Peanut (Arachis hypogaea) yield under irrigation levels in off-season cultivation. Revista de la Facultad de Ciencias Agrarias. Universidad Nacional de Cuyo. Mendoza. 53(1): 55-67.

12. Queiroz, A. A.; Queiroz, S. O. P.; Aragão, C. A. 2015. Reúso de efluentes domésticos na irrigação por gotejamento do tomateiro. Pesquisa Agropecuária Pernambucana. 20(1): 36-42. https:// doi.org/10.12661/pap.2015.006

13. Rocha, P. A.; Santos, M. R.; Donato, S. L.; Brito, C. F.; Ávila, J. S. 2018. Bell pepper cultivation under different irrigation strategies in soil with and without mulching. Horticultura Brasileira. 36(4): 453-460. https://doi.org/10.1590/s0102-053620180405

14. Saliba, R.; Callieris, R.; D’Agostino, D.; Roma, R.; Scardigno, A. 2018. Stakeholders' attitude towards the reuse of treated water reuse for irrigation in Mediterranean agriculture. Agricultural Water Management. 204: 60-68. https://doi.org/10.1016/j.agwat.2018.03.036

15. Santos, C. K.; Santana, F. S.; Ramos, F. S. M.; Faccioli, G. G.; Gomes Filho, R. R. 2018. Impacto do uso de efluentes nas características do solo cultivado com quiabo (Abelmoschus esculentus L). Revista Brasileira de Agricultura Irrigada. 12(4): 2276-2783. https://doi.org/10.7127/ rbai.v12n400975

16. Santos, C. S.; Santos, D. P.; Oliveira, W. J.; Silva, P. F.; Santos, M. A. L.; Fontenele, A. J. P. B. 2016. Evapotranspiração de referência e coeficiente de cultivo da pimenteira no agreste alagoano. Revista Brasileira de Engenharia Agrícola Ambiental. 10(5): 883-892. https:// doi.org/10.7127/rbai.v10n500458

17. Santos, H. G.; Jacomine, P. K. T.; Dos Anjos, L. H. C.; Oliveira, V. A.; Lumbreras, J. F.; Coelho, M. R.; Almeida, J. A.; Araújo Filho, J. C.; Oliveira, J. B.; Cunha, T. J. F. 2018. $5^{\circ}$ ed. Sistema Brasileiro de Classificação de Solos. Brasília, Embrapa Solos. 588p.

18. Sezen, S. M.; Yazar, A.; Tekin, S. 2019. Physiological response of red pepper to different irrigation regimes under drip irrigation in the Mediterranean region of Turkey. Scientia Horticulturae. 245: 280-288. https://doi.org/10.1016/j.scienta.2018.10.037

19. Silva, V. F.; Lima, V. L. A.; Nascimento, E. C. S.; Andrade, L. O.; Oliveira, H.; Ferreira, A. C. 2016. Effect of different irrigation levels with different qualities of water and organic substrates on cultivation of pepper. African Journal of Agricultural Research. 11(15): 1373-1380.

20. Silva, V. F.; Bezerra, C. V. C.; Nascimento, E. C. S.; Ferreira, T. N. F.; Lima, V. L. A.; Andrade, L. 2019. Production of chili pepper under organic fertilization and irrigation with treated wastewater. R. Bras. Eng. Agríc. Ambiental. 23(2): 84-89. https://doi.org/10.1590/18071929/agriambi.v23n2p84-89

21. Tavares, F. B.; Silva, A. C. R.; Fernandes, C. S.; Moura, K. K. C. F.; Travassos, K. D. 2019. Crescimento e produção de pimentão utilizando água residuária doméstica tratada. Revista Brasileira de Agricultura Irrigada. 13(5): 3683-3690. 10.7127/rbai.v13n5001131 